\title{
Legal Consequences for the Execution of Foreclosed Collateral (AYDA), Both for the Ownership of Collateral and for the Bank
}

\author{
Defrianta Sukirman; Kurnia Warman; Ulfanora \\ Faculty of Law, Andalas University, Padang, Indonesia
}

http://dx.doi.org/10.18415/ijmmu.v6i10.894

\begin{abstract}
As a sharia financial institution that carries out the intermediation function, Islamic banking has a risk of financing problems. This problematic financing does not only have an impact on the low income as a business institution, and ultimately results in the soundness of the bank. Settlement of problem financing is always sought in an efficient and effective way, with a minimum level of legal risk. This settlement effort is certainly inseparable from the provisions of the Islamic banking law, the the mortgages Act and the regulations of the financial services authority. One of the efforts to resolve the problematic financing allowed by the sharia banking law, and the regulation of the financial services authority is the Foreclosed Collateral (AYDA), even though this effort is contrary to the provisions of the mortgages Act. The problems in this thesis are four, namely first, the process of binding financing that is burdened with mortgagerights at PT. Bank Syariah Bukopin, Bukittinggi Branch. Secondly, the debt settlement process in financing encumbered with Foreclosed Collateral(AYDA) at PT. Bank Syariah Bukopin, Bukittinggi Branch. Third, concerning the legal consequences of the Foreclosed Collateral (AYDA), both for the ownership of collateral and for the Bank. Fourth, regarding the realization of the sale of Foreclosed Collateral (AYDA). This thesis research uses a sociological juridical research method, which moves from the existence of norm conflicts between laws and regulations related to efforts to resolve problematic financing by means of Foreclosed Collateral (AYDA), including its implementation at PT. Bank Syariah Bukopin, Bukittinggi Branch. The approach in legal sociology research, using the legislative approach and implementation practices, is carried out by reviewing and analyzing regulations regarding AYDA and implementation and the legal consequences of AYDA implementation. The results of the study indicate that the implementation of the AYDA is contrary to the mortgages Act and has legal risks in the form of null and void. For this reason, it is recommended that the implementation of the AYDA be avoided and steps taken to adjust the applicable provisions. This is to avoid not only legal risk for banks and customers as executors of existing regulations, but also to ensure the certainty and effectiveness of the laws that apply in the Republic of Indonesia.
\end{abstract}

Keywords: Mortgage Rights; Foreclosed Collateral (AYDA). 


\section{Introduction}

As an effort to realize prosperity for a just and prosperous Indonesian society based on Pancasila and the 1945 Constitution, one of its efforts is national development, with the most important part being economic development. This economic development, with the vast territory of the Republic of Indonesia, requires substantial funding and may not only be borne by the Government through the State Budget (APBN) alone.

Banking in the life of a country is one of the agents of development (agent of development), this is due to the main function of the bank itself, namely as an institution that collects funds from the community in the form of deposits and redistributes the community in the form of financing. This function is commonly referred to as financial intermediary function ${ }^{1}$.

As one of the financial institutions, based on Article 1 paragraph 2 of the Law of the Republic of Indonesia Number 21 of 2008 concerning Islamic Banking, the understanding of the Bank is as follows:

"Banks are business entities that collect funds from the public in the form of deposits and distribute them to the public in the form of loans and / or other forms in order to improve people's lives". Based on this definition, it can be interpreted that the bank is not only a place to engage with the community, but also has the function of distributing funds to the community in the form of financing and other forms, in order to improve the livelihoods of many people ".

Funding is a risky business, because there is the potential for payment failure or repayment by the customer, because many things can occur during the financing period, both from the internal and external sides of the customer and the bank itself. The greater the growth of financing in the banking sector, on the other hand there is the potential for increased risk of financing problems, because one indicator of the level of banking health is the level of Non Performing Finance (NPF). Even though banking health indicators, especially sharia banking, are not only about NPF, but based on Financial Services Authority Regulation Number: 8 / POJK.03 / 2014 concerning Health Level Assessment of Sharia Commercial Banks and Sharia Business Units, the assessment of the soundness of sharia banking uses a pattern riskbased approach with a self-assessment system, which generally includes risk profiles, good corporate governance, profitability; and capital.

Given the magnitude of the risk of financing faced by the banking sector, in practice, in each financing provision, the bank must conduct an in-depth analysis of the customer before a financing is approved. With regard to the approved financing proposals, the banks generally enter into a written financial agreement for each financing provided to customers, which generally consists of:

\section{Financing Agreement}

This agreement is the main agreement / master agreement in providing financing. This agreement can be carried out with notariil and internal certificates between the customer and the Bank.

\section{Agreement on binding collateral.}

This agreement is a contract / insurance agreement from the master agreement, to guarantee the financing facilities received by the customer, in accordance with the provisions of the applicable legislation. For banks, the binding of collateral is a secondary way out or a final solution for financing settlement if the customer defaults on the financing agreement.

\footnotetext{
${ }^{1}$ Abdul GafurAnshori, KapitaSelektaPerbankanSyariah di Indonesia, UII Press, Yogyakarta, 2008, hlm. 3.
} 
Among the general public and even a part of the banking community, although there are many factors that influence the valuation of financing, the collateral factor is considered to have a large role in providing financing, usually the greater the collateral value compared to the financing provided, the greater the possibility of financing can be melted. For the general public, there is an assumption that collateral and collateral are the same thing, even though there are differences between the two terms.

The term guarantee implies the ability of the debtor to fulfill or pay off his debt to creditors, which is carried out by holding certain objects of economic value as a liability for the loan or debt received by the debtor against his creditor ${ }^{2}$. From the point of view of banking law, the notion of collateral and collateral is not the same, as intended in the explanation of Article 8 paragraph (1) of Act Number 10 of 1998 concerning Amendments to Law Number 7 of 1992 concerning Banking, as follows:

"To reduce this risk, guarantee of granting credit or financing based on sharia principles in the sense of confidence in the ability and ability of debtor customers to repay their obligations in accordance with the agreement is an important factor that must be considered by the bank. To obtain this belief, before giving credit, banks must make a careful assessment of their character, ability, capital, collateral and business prospects of debtor customers."

"Whereas the definition of collateral is regulated in Article 1 number 23 of Act Number 7 of 1992 as amended by Act Number 10 of 1998: "Collateral is an additional guarantee that is surrendered by debtor customers to banks in the context of providing credit facilities or financing based on sharia principles."

Meanwhile in Article 1 number 26 of the Republic of Indonesia Law Number 21 of 2008 concerning Sharia Banking, there is no understanding of collateral, only an understanding of collateral, namely:

"Collateral is an additional guarantee, both in the form of movable and immovable objects submitted by the owner of the collateral to the Sharia Bank and / or UUS, in order to guarantee the repayment of the obligations of the recipient customer."

\section{Formulation of the Problem}

In connection with the above background, there are several issues that have become research problems, namely the legal consequences of the transfer of collateral (OREO), both for the ownership of collateral and for the Bank.

\section{Research methods}

This research is an empirical juridical law research, which is about debt settlement guaranteed by mortgage rights taken over by PT. Bank Syariah Bukopin, Bukittinggi Branch.

\section{Results and Discussion}

As a result of the implementation of the OREO, it certainly has legal consequences, both for the ownership of collateral, and for the PT. Bank Syariah Bukopin, namely:

1. Ownership of collateral.

\footnotetext{
${ }^{2}$ Rachmadi Usman, Hukum Jaminan Keperdataan, Sinar Grafika, Jakarta, 2009, hlm. 66.
} 
a. Collateral is still registered in the name of the owner of the previous collateral, but the owner of the collateral has given a power of attorney to the Bank, which has come into force 06 (six) months after the signing of the power of attorney.

b. In addition to the selling power, the collateral owner also signs the evacuation deed and voluntary submission of the collateral object, which also starts to take effect 06 (six) months after the signing of the deeds.

c. That after passing the option period, the customer no longer has the right to redeem the AYDA object and the ownership rights to the OREO object are fully the rights of the bank.

\section{PT. Bank Syariah Bukopin.}

a. The transfer of assets (collateral) from customers to the bank.

b. The purchase of part or all collateral, both through and outside the auction, based on voluntary surrender by the collateral owner or based on authorization to sell from the collateral owner, with the terms of the collateral purchased must be disbursed no later than 1 (one) year .

c. The Bank will immediately sell the OREO within a maximum period of 1 (one) year according to the Law concerning Islamic banking and not to have collateral for more than that period.

d. There is recording as an unproductive asset, as referred to in Article 1 paragraph 4 of the Financial Services Authority Regulation Number: 16 / POJK.03 / 2014 concerning Asset Quality Assessment of Sharia Commercial Banks and Sharia Business Units.

e. If there is an OREO that has more than 01 years, then the OREO is classified as a loss and the Bank is obliged to issue a reserve for the elimination of assets of $100 \%$ of the OREO value. The reserve for the removal of these assets is taken from the profit / profit of the Bank.

f. That after the redemption option period has expired, then the banking party has the right to fully use the AYDA object as well as the proceeds of the sale.

With the takeover of this collateral, for banks there are alternative financing solutions, especially for financing customers whose collateral is tied to the object of mortgage rights, namely by taking over collateral from troubled financing customers, in addition to settlement efforts stipulated in the Underwriting Rights Act. , namely through the following methods:

1. The right of the holder of the first-degree liability rights to sell the object of mortgages, as stipulated in article 6 of the Underwriting Rights Act.

2. Based on the executorial title contained in the certificate of mortgages as stipulated in article 14 paragraph (2) of the Underwriting Rights Act, by:

a. Auction

b. Sales under the hand.

The existence of the Collateral Taken (AYDA) provisions that allow banks to execute collateral other than those stipulated in the Underwriting Rights Act, causing this law to be ineffective in 
its implementation, even though it cannot yet be stated as a failure in implementing legislation - the invitation.

\section{Conclussion}

That towards the implementation of the OREO it certainly has legal consequences, both for the ownership of collateral and for the Bank. Although the AYDA's efforts are faster and more efficient, but based on the provisions of Article 12 and Article 20 paragraph 4 of the Underwriting Rights Law, it is expressly stated that every promise that gives authority to the holder of the Right of Rights to have an Underwriting Right object if the debtor is injured is canceled the law and every promise to carry out the execution of the Liability Rights in a manner contrary to the provisions of article 20 paragraph (1), paragraph (2), and paragraph (3) null and void. Thus the implementation of the OREO, based on the provisions of the Underwriting Rights above, is null and void by law, although in practice, the agreements made between the customer and the Bank remain valid for both parties, as long as there are no claims against the implementation of this agreement, which matters to the thesis this was made, there has not been a lawsuit against the implementation of the OREO. In the event of a court ruling that cancels the OREO agreement, then the provisions for implementing the OREO are based on Act Number 21 concerning Sharia Banking and Financial Services Authority Regulation Number: 16 / POJK.03 / 2014 concerning Asset Quality Assessment of Sharia Commercial Banks and Sharia Business Units is the way the Collateral Takes over (AYDA), raises legal risks and reputation risk for the banking sector and should be a serious consideration for both the policy makers and the banks in the future.

\section{References}

Book

Abdul Ghofur Anshori, Perbankan Syariah di Indonesia, Gajah Mada University Press, Yogyakarta, 2007.

Adiwarman A. Karim, Bank Islam Analisis Fiqih dan Keuangan, PT. RajaGrafindo Persada, Jakarta, 2004.

Adrian Sutedi, Hukum Hak Tanggungan, Sinar Grafika, Jakarta, 2012.

Agus Triyatna, Hukum Perbankan Syariah, Setara Press, Malang, 2016.

Effendi Perangin, Hukum Agraria di Indonesia, Suatu Telaah Dari Sudut Pandang Praktisi Hukum, Rajawali Pers, Jakarta, 2001.

Gatot Supramono, Perbankan dan Masalah Kredit, Suatu Tinjauan di Bidang Yuridis, PT. Rineka Cipta, Jakarta, 2009.

Gemala Dewi, Aspek-aspek Hukum Dalam Perbankan Syariah dan Perasuransian Syariah di Indonesia, Kencana Prenada Media Group, 2007.

M. Bahsan, Hukum Jaminan dan Jaminan Kredit Perbankan Indonesia, Raja Grafindo Persada, 2007. Sudikno Merto Kusumo, Mengenal Hukum (Suatu Pengantar), Liberty 1991

Sutan Remy Sjahdeini, Perbankan Islam danKedudukannyaDalam Tata HukumPerbankan Indonesia, PT. PustakaUtamaGrafiti, Jakarta, 2005.

Zainudin Ali, Metode Penelitian Hukum, Sinar Grafika, Jakarta, Cetakan Keempat, Juni 2013 


\section{Legislation}

Undang-Undang Nomor 5 Tahun 1960 Tentang Peraturan Dasar Pokok-Pokok Agraria.

Undang-Undang Nomor 4 Tahun 1996 tentang Hak Tanggungan Atas Tanah Beserta Benda-Benda Yang Berkaitan Dengan Tanah

Undang-undang Republik Indonesia Nomor 10 Tahun 1998 Tentang Perubahan Atas Undang-Undang Nomor 7 Tahun 1992 tentang Perbankan.

Undang-undang Republik Indonesia Nomor 21 Tahun 2008 Tentang Perbankan Syariah.

Undang-undang Republik Indonesia Nomor 2 Tahun 2014 Tentang Perubahan Atas Undang-Undang Nomor 30 Tahun 2004 tentang Jabatan Notaris.

Peraturan Otoritas Jasa Keuangan Nomor : 16/POJK.03/2014 Tentang Penilaian Kualitas Aset Bank Umum Syariah dan Unit Usaha Syariah

Fatwa Dewan Syariah Nasional

Fatwa Dewan Syariah Nasional Nomor 04/DSN-MUI/IV/2000, tertanggal 01 April 2000 tentang Murabahah

Fatwa Dewan Syariah Nasional Nomor 05/DSN-MUI/IV/2000, tertanggal 04 April 2000 tentang Jual Beli Salam

Fatwa Dewan Syariah Nasional Nomor 06/DSN-MUI/IV/2000, tertanggal 04 April 2000 tentang Jual BeliIstishna

Fatwa Dewan Syariah Nasional Nomor 07/DSN-MUI/IV/2000, tertanggal 04 April 2000 tentang Mudharabah Fatwa Dewan Syariah Nasional Nomor 08/DSN-MUI/IV/2000, tertanggal 13 April 2000 tentang Musyarakah Fatwa Dewan Syariah Nasional Nomor 47/DSN-MUI/II/2005, tertanggal 17 Februari 2005 tentang Penyelesaian Piutang MurabahahBagi Nasabah Tidak Mampu Membayar

\section{Copyrights}

Copyright for this article is retained by the author(s), with first publication rights granted to the journal.

This is an open-access article distributed under the terms and conditions of the Creative Commons Attribution license (http://creativecommons.org/licenses/by/4.0/). 